Copyright (c) 2015 by Academic Publishing House Researcher

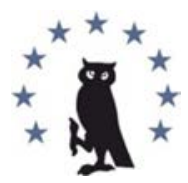

Published in the Russian Federation

European Researcher

Has been issued since 2010 .

ISSN 2219-8229

E-ISSN 2224-0136

Vol. 94, Is. 5, pp. 356-364, 2015

DOI: $10.13187 /$ er.2015.94.356

www.erjournal.ru

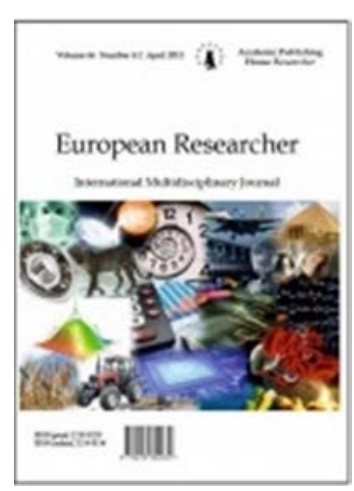

Economic sciences

Экономические науки

UDC 327

\title{
Kazakhstan and America: the Frontiers of Energy Diplomacy
}

\author{
Bekbolat Almadiyev
}

Academy of Public Administration under the President, Kazakhstan

$\mathrm{PhD}$

E-mail: idt12@mail.ru

\begin{abstract}
The article describes the development and use of policy instruments and tools for energy cooperation promotion between Kazakhstan and the United States. The role of energy diplomacy in foreign policy strategy of the Republic of Kazakhstan is due to the progressive growth of the relationship between the economic interests of Kazakhstan and the United States.

The main objectives of the energy policy of the Republic of Kazakhstan are: the internal energy market formation, energy supplies on a competitive basis and energy security provision, as well as the improvement of the environmental sustainability of the energy.

Modern American transnational enterprises have at their disposal significant financial resources, technological and managerial capacity. They are able to develop oil and gas fields effectively in the Republic of Kazakhstan with the least financial costs and minimal environmental damage.

Keywords: energy diplomacy, political mechanisms, efficiency, foreign policy, energy resources, technological potential, geopolitics, energy security, international consortium, temporary transport, innovative energy sources.

Acknowledgment: I express my heartiest gratitude to the editors, interpreters and all those who shared the difficulties with me in publishing this work. I highly appreciate your approachability and willingness to help me. I hope to work with you in the future

\section{General problem statement and its relation with important scientific and practical issues.}

One of the priorities of Kazakhstan's foreign policy is the development of relations with the United States, associated with the following objective reasons:

1. First, the United States is a world superpower, exerting a significant impact on the development of global political and economical processes;
\end{abstract}


2. Second, the US economy is one of the most competitive in the world. The experience in the economic grouth of the United States is valuable for Kazakhstan at the present stage, including the tasks in the Strategy the ranking of Kazakhstan among 50 most competitive countries of the world.

3. Third, the experience of the democratic development of the United States, as well as constitutional development seems no less valuable for Kazakhstan in the light of the upcoming constitutional reforms.

For the Republic of Kazakhstan one of the most important issues, along with socio-economic issues in the country, was the adoption of the republic in the international arena. The absence of his Foreign Minister in the period of Kazakhstan accession into the Soviet Union, diplomatic experience in conducting relations with foreign states exacerbated the situation. A young country had to start with a "blank sheet", and the creation of the Ministry of Foreign Affairs was the first sign. The recognition of the independence of the Republic of Kazakhstan from the international community, as well as the need for economic and political contacts with foreign countries required immediate actions [3].

An integral part of US foreign policy is economic assistance to the newly independent states on a bilateral basis, the attraction of developed western countries and international financial institutions for providing such assistance and encouraging the US private sector to invest in the economy of these countries

One of the two most important for Kazakhstan countries is the United States of America. They had been the guarantors of the sovereignty and security of our country in the derivation of nuclear weapons and provided substantial international recognition of Kazakhstan.

\section{Analysis of recent researches and publications in which the decision is based on the problem with the due consideration of the author.}

The beginning of Kazakh-American relations was laid in December 25th 1991 with the official recognition of Kazakhstan by the United States as a sovereign state. On the next day, 26 December, between the two countries full diplomatic relations at ambassadorial level was established.

Energy diplomacy as a form of economic diplomacy is extremely important for the Republic of Kazakhstan as a whole, and for the Kazakh-American relations either.

Nowadays energy issues in the world play a significant role in determining strategies of the foreign policy in the relationship of states. Energy diplomacy is the one of the main tools of implementing these strategies. At the same time geopolitics plays the role of the direction coordinator of diplomatic means and methods aiming to establish mutually beneficial cooperation between states in the energy sector.

Energy diplomacy and geopolitics of the Republic of Kazakhstan and the United States are part of the issues on foreign energy policy, directly characterizing the development of international energy law along with energy security, the international institute of energy law (universal and regional organizations), energy markets, energy industries and infrastructures, the world energy environment.

In the last decades of the XX century external energy policy of Kazakhstan and the United States was formed as a separate functional area. Its formation is directly related to such factors as foreign economic interests and geopolitics of the state.

According to proved oil reserves Kazakhstan is on the ninth place in the world. It is proved that there are 6.5 billion tons of oil reserves in the bowels of Kazakhstan, and according to forecasts these reserves reach 20-25 billion tons. Stable growth of the welfare of the country and the citizens, great prospects, developing economy, international cooperation and, of course, the recognition of Kazakhstan by the international community - all of these gave the possession of the "black gold".

Over 10 years of independence, the total oil production made up 100 million tones, of which 25-30\% was produced in the Tengiz field. According to forecast of experts by 2015 this figure will increase up to 150 million tons of oil extracted mainly from the Kashagan field (about 50\%).

There is a great number of oil companies in Kazakhstan engaged in the field development and production of oil. They are introduced both by Kazakhstan and foreign enterprises. According to the "Statistical Review of World Energy" prepared by the British company BP by the end of 2012 Kazakhstan was on the $12^{\text {th }}$ place by oil reserves and $21^{\text {th }}$ by gas reserves.

British BP has estimated oil reserves in Kazakhstan at the level of 30 billion barrels, or 3.9 billion tons, which amounts to $1.8 \%$ of the world reserves. Venezuela (46.5 billion tons, $17.8 \%$ ), 
Saudi Arabia (36.5 billion tons, 15.9\%) and Canada (28 billion tons, 10.4\%) are the leaders on oil reserves. End of 2012 the global oil reserves made up 235.8 billion tons.

The gas reserves in Kazakhstan amounted to 1.3 trillion cubic meters $(0.7 \%$ of world reserves). This is number 21 in the rankings, Kazakhstan divides this place with China and India. Most of the world's gas reserves are in Iran (33.6 trillion cubic meters, 18\%), Russia (32.9 trillion cubic meters, 17.6\%) and Qatar (25.1 trillion cubic meters, 13, 4\%). In general, the world's proven gas reserves amounted to 187.3 trillion cubic meters.

According to experts of the Department of Energy of the United States, forecast resources in Kazakhstan, including the Caspian shelf, for all types of hydrocarbons are estimated from 8 up to 18 billion tons, or from 58 up to 130 billion barrels of oil equivalent. American experts believe that the only forecast reserves in the Kazakh sector of the Caspian Sea may reach 5 to 12 billion tons, or 36 to 88 billion barrels of oil equivalent.

There is a great number of oil companies in Kazakhstan engaged in the field development and production of oil. They are introduced both by Kazakhstan and foreign enterprises [2].

KazMunaiGas is the largest national oil and gas company engaged in the exploration, production, processing and transportation of oil. This is a joint-stock company with $100 \%$ share of state. The assets of the company are: KazakhOil-Aktobe (67\%), Mangistaumunaigas (50\%), PetroKazakhstan (33\%), TCO (20\%) and etc.

Also the following smaller Kazakh oil companies carry out their activities: AdayPetroleum, Tolkunneftegas, Aktau Transit, ANAKO (first private oil company - 1994), AI-DAN-munai and etc.

The United States is the largest investor in Kazakhstan's economy and one of the main trading partners. The total volume of US investments in Kazakhstan exceeded 12 billion. US dollars, which is almost one-third of all foreign investments. Together with investments US companies have brought Kazakhstan new knowledge, innovation and technology.

The main investors in the oil and gas sector:

1. Exxon Mobil Corporation - a major private oil company in the world. Has a 7,5\% stake in Caspian Pipeline Consortium, 16,81\% stake in Kashagan and 25\% in Tengiz.

2. Chevron - the second major American oil company. Holds shares in a Caspian Pipeline Consortium - 15\%, also has 50\% stakes in Tengiz and 20\% in Karachiganak.

3. Conoco Phillips - one of the major American oil companies. Holds shares in Kashagan -

In 2008 American oil companies (together with the European) accounted for $42 \%$ of the total shares on Kazakhstan oil market.

The starting point of cooperation between Kazakhstan and the US oil companies can be considered as April 6, 1993, when "the contract of the century" was signed. Kazakh government signed an agreement with Chevron for a period of 40 years [4].

Together with J SC "Mubadala Development Company" (UAE) is involved in the exploration and production of the unit " $\mathrm{H}$ " on the Caspian shelf (24.5\% share).

3 major fields, which are invested by Americans, should be mentioned separately 3:

1. Kashagan field (together with Kairan, Aktoty, Kalamkas sea) - have 5,428 billion tons of total oil reserves and 1,688 billion tons of recoverable oil.

2. Tengiz field has 3,1 billion tons of total oil reserves, of which 0,75-1,1 billion tons recoverable oil reserves. What is more, the Korolevskoe field with its 188 billion tons of total oil reserves is situated in close proximity.

3. Karachaganak field - total booked reserves amounts to more than 1 billion tons of oil, gas and gas condensates.

Shevron produces oil at Tengiz, Kashagan, Karachiganak.

Other American companies such as ExxonMobil (Tengiz, Kashagan), ConocoPhillips (Kashagan) are working quite successfully in the oil market of Kazakhstan.

According to experts of the Agency of the Republic of Kazakhstan on investments, the volume of direct investments of US companies in the oil and gas sector of the country at the beginning of 1999 amounted to more than 1.9 billion US dollars or $70 \%$ of all foreign investments in Kazakhstan's oil and gas projects.

Development of energy cooperation between Kazakhstan and the United States is an important factor in the economic growth of our country. In the context of upcoming production volumes increase of oil and gas resources in Kazakhstan multi-vector policy directions of 
hydrocarbon exports and maximal use of pipelines is becoming important. Therefore, Kazakhstan is interested in continuing cooperation with the US in the energy sector, including diversifying export routes for oil and gas.

According to prediction of experts of the US Department of Energy, after the beginning of exploitation of the Caspian Sea, oil production can be increased up to 170 million tons of oil per year, or 3.4 million barrels a day.

Today US oil companies are engaged in the major Kazakhstan:

1. JV LLP «Tengizshevroil» with the involvement of Chevron and Mobil (Chevron - 45\%, Mobil - 25\%, LUKArco - 5\%, NOK “Kazakhoil” - 25\%);

2. International consortium «Kazakhstancaspishelf» with the involvement of Mobil and PhillipsPetroleumCo. (according to the agreement on production sharing Caspian offshore project, the total income of the partners for 40 years of operation will be around 600 billion US dollars);

3. The development of the Karachaganak field (Texaco - 20\%). Total revenues in the development of oil and gas condensate field are estimated at 35billion US dollars;

4. JV «Arman» oil field development in Mangistau region with the participation of the company Oryx (50\%). Oil production in 1998 amounted to 247,857 tons;

5. Codevelopment of the «Mertviy Kultyk» site with the involvement of Oryx и Exxon companies;

6. JV «Tulpar-Munai Ltd.» hydrocarbons exploration and production in the oil fields of Aktobe and West Kazakhstan region with the participation of Mobil;

7. Severny Buzachi field development with the involvement of Texaco company (65\% share);

8. Caspian Pipeline Consortium (Chevron - 15\%, Mobil- 7,5\%, Oryx - 1,75\%, LUKArco $12,5 \%)$

9. The owns and operates the 97.5-percent of stake in the Sazankurak oil field and has shares in the amount of $51.83 \%$ in the joint venture " LLP Condensate Holdings ", created to develop Chinarevsky oil and gas condensate field. FIOC also owns $22.5 \%$ of the joint venture "CentralAsiaOil" which deals with oil exploration in the Caspian region. [6] article.

III Pointing out unsolved parts of the general problem, which are noted in the

Taking an active part in the development of Kazakhstan's energy resources, the US oil companies noted a lack of capacity of existing export pipelines. Currently, the delivery of crude oil to the world markets is carried out both through Russian pipeline system and the so-called "temporary transport schemes" by sea and railway transports. The share of "temporary option" amounts to, as estimated by Kazakh experts, at least $50 \%$ of the total volume of oil exported.

Through the development and use of policy instruments and tools for effective energy diplomacy of the Republic of Kazakhstan and the United States, both countries will take measures to reduce barriers on the way to investment and trading in the energy sector.

To improve the efficiency of energy production and consumption on a global scale it is especially important that companies from producing and consuming countries had the opportunity to invest on a reciprocal basis and to acquire energy assets in the field of exploration and production, processing and marketing in other countries, at the same time respecting the rules of competition struggle.

The formation of investment flows between Kazakhstan and the United States on the basis of market mechanisms will also contribute to improve energy security by increasing confidence in access to markets or sources of supply.

The main political mechanism to implement effective energy diplomacy of the Republic of Kazakhstan and the United States are:

1. The creation of a favorable economic environment for the operation of the fuel and energy

2. y complex (including coordinated tariff, tax, customs, antitrust regulation and institutional reforms in the energy sector);

3. The introduction of perspective technical regulations, national standards and norms, improving the manageability and promoting the implementation of the most important priorities and guidelines of energy development, including energy efficiency of the economy; 
4. The promotion and support of strategic initiatives of economic entities in the investment, innovation, energy-saving, environmental and other areas of priority;

5. The improvement of the efficiency of state property management in the energy sector.

The achievement of energy diplomacy between Kazakhstan and the United States is based on the realization of all the main components of the state energy policy between the two countries, in light of the following key mechanisms:

1. To provide warranty and reliability of energy supply and the economy of the country to the full extent in normal conditions and in the minimum extent under the threat of emergency situations of different nature through the creation of strategic reserves of energy resources, regulation of minimum allowable reserves generating capacity and energy transport, levels of seasonal fuel reserves, equipment reserves necessary to remedy consequences of major accidents in the energy sector;

2. To share powers and responsibilities of the state bodies, bodies of executive power of the federal and regional levels, energy saving companies and business-consumer entities in terms of energy security of all economy sectors, population, social facilities and enterprises;

3. To ensure reliable operation and predictable development of energy infrastructure, including the use of mechanisms of public and private partnerships, a consistent elimination of restrictions for energy resources transportation between different regions of the country, as well as between regional production complexes (load centers) within regions;

4. Timeliness of exploration, preparation and development of new fields (deposits, areas, regions, provinces) of traditional fuels, including the use of public and private partnerships and rational tax policy (meaning the outpacing production grouth of proven recoverable reserves), timeliness of the use of substitute energy \and innovative energy sources due to the exhaustion of traditional fossil fuels;

5. To prevent depreciation level of fixed assets, which launch threats against energy security and to promote the investment attraction for their modernization through the introduction of mechanisms for the investment credit against tax, tax breaks for the project payback period, abnormal depreciation and investment risks insurance;

6. The maximum possible use of competitive domestic equipment in all processes and projects to stimulate the development of domestic energy production with a high added value and improve the quality of petroleum products due to tightening of fuel quality standards, modernization of oil and gas processing facilities in Russia, the differentiation of excise rates for motor fuels of varying quality;

7. The increase of national energy security as a result of international cooperation in the energy sector while guarantee performance of obligations under international export contracts for the supply of energy resources [5].

The energy efficiency diplomacy of the Republic of Kazakhstan and the United States can be achieved through optimal pricing policy and the reform of the electricity in the country, the introduction of energy-efficient technologies and organizational measures more rational use of energy resources. There should be an intensive implementation of organizational and technological measures to save fuel and energy. These measures include the development of mechanisms for the economic interest of companies to comply with regulations and energy efficiency standards as benchmarks of the use of economic instruments and rational use of energy.

Kazakhstan, which accounts for 75 percent of estimated hydrocarbon reserves of the Caspian basin, is interested in further expansion of the presence of US companies in its energy sector. Even today, the United States is the largest investor in Kazakhstan, international companies with US residence permit such as "ChevronTexaco", "ExxonMobil", "ConocoPhillips" and others are operating in Kazakhstan. The share of US companies accounts for nearly 10 billion US dollars of investments or about one-third of the total foreign investments in Kazakhstan since independence. At the meeting reciprocal interest of US firms to expand its presence in Kazakhstan was marked, including the future development of fields in the Caspian Sea.

The discovery of new oil fields in the north of the Caspian Sea played a positive role. The US administration takes the Caspian region to the forefront of its foreign policy and actively promotes the interests of US companies in the Caspian countries. 
IV Research objective statement (task statement).

The objective of the article is to analyze the development and use of policy instruments and tools for effective energy diplomacy of the Republic of Kazakhstan and the United States. results.

$V$ The main results of the research work with full justification of scientific

During the years of independence the trade -economic and investment cooperation with the US was developing very dynamically. Kazakhstan has consistently defended the position in the negotiations with US officials on the status of Kazakhstan's low-enriched uranium, the removal of the 15 per cent import duty and inclusion in the General System of Preferences (GSP) of Kazakh titanium sponge. Negotiations continued with the resumption of anti-dumping proceedings in respect of exports to the US steel products from Kazakhstan. There were also consultations on facilitating the accession of Kazakhstan to the United States in the WTO.

The cooperation with the American business in the oil and gas sector is of a particular importance. US companies with the support of the political leadership of the United States are currently engaged in the entire production chain - from research to production, processing and transportation of hydrocarbons and derived products.

Currently almost all major US oil companies are involved in the implementation of almost all the major projects in the oil and gas sector 'Kazakhstan. The seriousness of plans of US companies is confirmed by the fact that their activities are not limited to oil production, and includes projects of complex processing of raw materials, creation of local infrastructure, addressing environmental and social issues.

As mentioned above, the first American company, which came to the Kazakh market, was "Chevron", which signed 20-billion contract with the Government of Kazakhstan to develop one of the world's largest Tengiz in 1992. Within the contract a joint venture "TCO" in which the US company has a 45 percent share was created. Later on another US oil company - "Mobile" had entered the joint venture Already in 1998, "TCO" got 8.5 million tons of oil, accounting for 30 percent of all extracted oil in our country (in 2000, oil production in Kazakhstan has exceeded 30 million tons).

When speaking about the activities of "Chevron", it is important to note that the total revenue from crude oil at Tengiz and Korolev fields for forty years should reach 50 billion US dollars. Having started the development of the Tengiz field in 1993, "Chevron" by the end of 1997, provided a profit of 80 million US dollars. Making a profit in such a short time - it is a success, what the company did not have in any other country in which it conducted the development of hydrocarbons. In 2000, Kazakhstan's budget received in dividends and royalties more than 700 million US dollars.

Today the US company Chevron is considering the possibility of cooperation with KPI (KazakhstanPetrochemicalIndustries) in the construction of a gas chemical complex in the western part of Kazakhstan. The head of the Kazakh Ministry of Energy Vladimir Shkolnik appreciated such a prospect.

The gas chemical complex is being built in Atyrau. It is expected that in 2016 the company will start producing polyethylene and polypropylene. The complex will receive gas from the Tengiz oil field being developed by JV "Tengizchevroil". South Korean company LG Chem who had entered in 2011 into a contract with KPI for 4 billion US dollars participates in the project, the cost of ammounts from 5 to 7 billion US dollars.

In 1997 a production sharing agreement between Kazakhstan and a consortium of companies, where along with the American company "Texaco" the British "British Gas" and Italian "Agip" is involved, for the development of the Karachaganak gas condensate field was signed. The project is timed for forty years, and will be implemented until 2036. The design capacity of the production at Karachaganak is 12 million tons of oil and 25 billion cubic meters of gas. The contractor is an American company "Bechtel", providing engineering and procurement works for the expansion of existing production facilities, additional export pipelines and new infrastructure necessary to support the project.

Great expectations are associated with the development of oil production at Kashagan field in the Kazakh sector of the Northern Caspian sea. In accordance with the encouraging results of the seismic analysis in this sea zone there was formed an international oil consortium OKIOC, who became the operator of a six-year exploration program under the Production Sharing Agreement, 
signed in Washington in 1997 between the Republic of Kazakhstan and the members of the consortium. It included the American company "Mobile" and "Phillips Petroleum".

OKIOC provides research development and production of oil on 10 of the 200 units of the Kazakhstan sector of the North Caspian sea. Estimated reserves of oil reserves are 4 billion tons. The consortium plans to spend over 6 years, about 450 million US dollars, of which 220 million US dollars will be spent for the original drilling. At the same time OKIOC started the research drilling in the late summer of 1999. It is significant that the United States announced the results of drilling on the continental shelf of the Caspian Sea the most important discovery in the world in the last thirty years.

For several years the "Texaco" company is successfully operating on the other major northern field Buzachi in Mangistau region.

US service companies are actively involved in energy projects realization. "Bechtel", "FlyuorDaniel" "AmeradaHess" are among them. Besides the fact that "Bechtel" is the contractor company of the "TCO" at the Tengiz field and Karachaganak international consortium at the Karachaganak field, the company carried out the reconstruction of the Aktau sea trade port.

American companies are the suppliers of drilling equipments, which is very important for Kazakhstan, where still no capacity requirements for their production. In 1997 equipment for oil and gas development was imported from the US for the amount of 12.8 million US dollars, in 1998 - 23 million US dollars. Nevertheless, the prospects for cooperation in this sphere between Kazakhstan and American producers for drilling equipment, taking into consideration that the demand of Kazakhstan is estimated at 1 billion US dollars, is very favorable.

The American company "Chevron", "Arco" (through participation in the joint venture "LukArco" with the Russian company "Lukoil"), "Mobile" and "OrixEnergy" are involved in the project on the construction of the Caspian Pipeline Consortium (CPC). CPC is designed for export pipeline construction from the Tengiz field to the Black Sea port of Novorossiysk with the lenght of 1.5 thousand kilometers. The planned capacity - is 28 million tons of oil per year, which, after completion of the works on expanding the capacity of the pipeline (not before 2005) will be 67 million tons of oil per year. The main contractor is the American company "FlyuorDeniel." The construction of Tengiz-Novorossiysk pipeline had started on May 12, 1999.

In March 1999, the company "Kazakh Oil" has signed an agreement with the United States Trade and Development Agency on grant-in-aid for funding a feasibility study of the project on the establishment of a national database of research and production of oil and gas, as well as creating a Petroleum Information Service. The feasibility study is being developed by American companies "Mestek International" (Virginia) and the Centre "Sakeyz Energy» of the Oklahoma University.

It is symbolic that the publication in January 2001 of the Decree of President Nursultan Nazarbayev on the establishment of the National Fund coincided with the transfer of a US company "Chevron" 660 million US dollars in exchange for a 5 percent stake in the joint venture "TCO"

The particular importance of the energy factor is underlined by the fact, jointly with Eximbank, the Agency for Trade and Development of the United States and the Overseas Private Investment Corporation (OPIC), of creation of the Caspian Finance Center. The center was established to promote the various economic projects in Kazakhstan, especially in view of the need for large-scale projects of oil and gas infrastructure in the Caspian Sea.

As part of a global strategy to ensure energy security of the United States the American leadership pays special attention to the establishment of export pipeline infrastructure from the Caspian region. In this direction the Administration of U. Klinton pursued a policy of multi-variant pipeline in order to ensure uninterrupted supply in the future Caspian oil to the world market based on the interchangeability of export routes of transportation. [8]

When meeting with the president Nazarbayev in Washington in November 1997 the Deputy state secretary S. Telbott stressed the importance of addressing complex transportation problems for the future of Kazakhstan, saying that "the United States will support all developed and new routes of hydrocarbon exports, except Iran, in all directions along the axis of the East-West and North-South ".

The continuity of energy policy has been maintained after the change of administrations. In early 2001, the president George W. Bush in a special report "The new US energy policy" stressed that "potential exports from the Caspian region could reach 1.8 million barrels of oil per day by 
2005, as the United States will work closely with private companies and countries in the region for the development of commercially viable export routes, as Baku-Tbilisi-Ceyhan oil pipeline and the CPC ... The US-backed "East-West" pipeline routes will add a new oil transport capacity that will continue to increase production and exports".

The Visits of S. Sestanovich, the coordinator of the US policy toward the NIS, to Kazakhstan in July 2000, and B. Richardson, the US Secretary of Energy, in august - were devoted to strengthening further cooperation in the field of energy. The prospect of an alternative, stable source of oil from the Caspian region intensified lobbying of the export pipeline project BakuTbilisi-Ceyhan.

The position of Kazakhstan in relation to the pipeline remains generally positive, especially since this project cannot be realized without Kazakh oil. Not having any political reservations on the project, Kazakhstan proceeds from the commercial viability of the pipeline. Astana considers the project of the Caspian Pipeline Consortium to be a priority one, whereupon not excepting its participation in the Baku-Tbilisi-Ceyhan pipeline project.

At present, the American investor - the company AES controls 30 percent of all Kazakh assets for the production of electric energy. Since 1996 the company had invested more than 150 million US dollars in the power sector of economy of the Republic of Kazakhstan. In August 1996, AES acquired Kazakhstan's largest GRES- 1 with capacity of 4 thousand megawatt. In the autumn of the following year the company had acquired four thermal power stations and power plants, signed two agreements on management of two hydroelectric power stations in the eastern Kazakhstan region. In summer 1999, AES had reached an agreement with the government to transfer in trust the management of several regional companies on electricity transporting.

According to US experts, the clinching factor in overcoming obstacles on the way to the rapid advance of the oil resources of the Caspian Sea to the world market, will be an effective cooperation between the CIS countries, on the one hand, and foreign investors, especially from the United States - on the other hand. The key to the development of the region based on the sale of oil is the construction of large export, internationally recognized pipelines [7].

The United States welcomes the access of Kazakh energy resources to world markets. The influx of "petrodollars" to the economy of Kazakhstan, as a factor of stability, would create at the same time maximum opportunities for the US and other foreign companies to participate in the development of the investment field of the Republic of Kazakhstan.

\section{direction.}

VI Findings from this study and the prospects of the latest developments in this

Making conclusions on the development and use of policy mechanisms and tools for effective energy diplomacy of the Republic of Kazakhstan and the United States the following strategic initiatives can be pointed out:

1. The development of private and state partnerships while energy projects realization; sector;

2. The development of risks insurance system of a long-term investment to the energy

3. The creation of joint leasing companies to provide energy sector organizations with advanced technologies and equipments;

4. To promote economic motivation of the activity of small and medium-sized businesses in the energy sector with due regards to industrial characteristics and venture innovative production;

5. To promote technical upgrading, innovation development of enterprises and industries of the fuel and energy complex;

6. To organize and promote training of fuel and energy complex workers of all levels.

\section{References:}

1. Eurasian Centre for Political Researches and "Epicentre" Agency for social technologies. "Influence groups" in political systems of the Republic of Kazakhstan. Online newspaper "Navigator", November 29, 2005. http:// zonakz.net/ articles/ 10280

2. In the near future Kazakhstan will establish a program on atomic energy development. Kazakhstan today, March 6, 2006.

3. Keleshek R. They are interested in Kazakhstan’s way//Kazakhstanskaya Pravda. №${ }^{\circ}{ }^{2}$. February 27, 2007. 
4. Oil and gas potential for the sake of Kazakhstan nation. KazMunaiGas. Almaty: Rayan 2006, p74-86.

5. Politics and interests of World Powers in the Republic of Kazakhstan. Almaty, 2002.

6 . The concept for uranium industry and nuclear power engineering of the Republic of Kazakhstan for the years 2002-2030.

7. The issue of atomic energy development is not considered at the official level - the head of the Ministry of Environmental Protection. Kazakhstan today. May 22, 2006.

8. The United States considers the possibility of constructing 19 new AES - George Bush. RIA News. 21 February, 2006. 